\title{
Shifting boundaries of racial space in post-apartheid South Africa: The case of Afrikaner youth in East London
}

\begin{tabular}{|c|c|}
\hline \multicolumn{2}{|c|}{$\begin{array}{l}\text { Authors: } \\
\text { Luvuyo Ntombana }{ }^{1} \\
\text { Thandiwe Bubulu }\end{array}$} \\
\hline \multicolumn{2}{|c|}{$\begin{array}{l}\text { Affiliations: } \\
\text { 'Department of Sociology } \\
\text { and Anthropology, Nelson } \\
\text { Mandela University, } \\
\text { South Africa }\end{array}$} \\
\hline \multicolumn{2}{|c|}{$\begin{array}{l}{ }^{2} \text { Center for Leadership Ethics } \\
\text { in Africa, University of Fort } \\
\text { Hare, South Africa }\end{array}$} \\
\hline \multicolumn{2}{|c|}{$\begin{array}{l}\text { Corresponding author: } \\
\text { Luvuyo Ntombana, } \\
\text { ntombanal@ufs.ac.za }\end{array}$} \\
\hline \multicolumn{2}{|c|}{$\begin{array}{l}\text { Dates: } \\
\text { Received: } 15 \text { Mar. } 2017 \\
\text { Accepted: } 24 \text { Aug. } 2017 \\
\text { Published: } 17 \text { Nov. } 2017\end{array}$} \\
\hline \multicolumn{2}{|c|}{$\begin{array}{l}\text { How to cite this article: } \\
\text { Ntombana, L. \& Bubulu, T., } \\
\text { 2017, 'Shifting boundaries of } \\
\text { racial space in post-apartheid } \\
\text { South Africa: The case of } \\
\text { Afrikaner youth in East } \\
\text { London', The Journal for } \\
\text { Transdisciplinary Research in } \\
\text { Southern Africa 13(1), a432. } \\
\text { https://doi.org/10.4102/ } \\
\text { td.v13i1.432 }\end{array}$} \\
\hline \multicolumn{2}{|c|}{$\begin{array}{l}\text { Copyright: } \\
\text { ( 2017. The Authors. } \\
\text { Licensee: AOSIS. This work } \\
\text { is licensed under the } \\
\text { Creative Commons } \\
\text { Attribution License. }\end{array}$} \\
\hline \multicolumn{2}{|l|}{ Read online: } \\
\hline 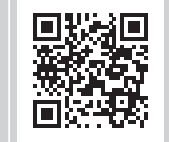 & $\begin{array}{l}\text { Scan this QR } \\
\text { code with your } \\
\text { smart phone or } \\
\text { mobile device } \\
\text { to read online. }\end{array}$ \\
\hline
\end{tabular}

South African democracy has brought about changes like freedom of associations, as opposed to apartheid which emphasised separateness of races and cultures. This social change warrants new ways of living among South Africans, especially among young people. Using a qualitative approach with semi-structured interviews, this study examined how white Afrikaans-speaking university students carve out their identities, given the reality that political, social and cultural circumstances have changed in the last two decades. Participants consisted of Afrikaner university students, based in East London. This study attempts to understand difficulties and privileges associated with being a young white South African 20 years after the fall of the apartheid regime. Seeing that the participants were not born during apartheid, we wanted to understand the extent to which their parents' perception, influence and stories affected the way participants identify themselves, their place and their roles in the democratic South Africa. The study found that Afrikaner youth are caught between two worlds: the democratic and contemporary social context, and their parents' traditional or orthodox way of seeing things. This study also found out that, in spite of some of their parents' influence on racism and the perception of the South African community about white people, these young people are able to carve out their own identity in which they are able to shift racial space boundaries.

\section{Introduction}

Recently, South Africa has been affected by racial conflicts and serious racism utterances from both black South Africans and white South Africans. Some of those racial expressions and complexities are because of a deep-seated pain and division that was caused by the apartheid experience (Puttick 2011:1). To some extent, it is understandable when such racist tendencies are exhibited by older generations who have had direct experience of apartheid. However, one tends to ask various serious questions when young people, who were either very young or had not been born as yet when apartheid and its racial policies were in effect, exhibit such tendencies. There have also been cases of serious racist allegations among university students in the country and most of those who were involved were youth, who did not have direct experience of apartheid. For instance, Goga (2010:41) notes that at a university in the Eastern Cape, racist utterances on the university's online discussion forums led to its use being temporarily suspended in 2006. Similarly, the University of Free State has been the site of numerous spates of racism. In 2007, four white students reportedly made a racist video in which black cleaners were made, among other things, to eat food said to have been urinated on (Soudien 2010). Also, at the same university, in 2016, there was a violent clash between young black people and white people, and some of those involved were the so-called 'born-frees', those born after apartheid.

Research also suggests that South Africa is not a unified country and that racial differences persist and also exert their power over every feature of our lives (Dyer 1997; Gibson \& Mcdonald 2001; Goga 2010; Vincent 2008). It is a reality that South African society is still racially divided and that many white people still find themselves in a position of privilege, while many black people are still poor and marginalised (Beall, Gelb \& Hassim 2005:683; Sehlongonyane 2015:84). In this paper, we acknowledge the realities as depicted in the media and various research papers. However, we also recognise that there are many layers of realities in South African society and such layers must also be uncovered. This paper presents a different picture than what most people have seen and read in the democratic South African media. This paper shows that as much as South Africa is still a racially divided space, wherein white people are still privileged, some white people in other spaces attempt to shift racial boundaries and are able to create an inter-racial identity. The contention is that, as a result of racial tensions and a divided society, 
South Africans seem to overlook the positive stories of how youth in other spaces are able to carve out new identities, irrespective of the divided society and the negative stories. This study shows that some Afrikaner youth living in East London are able to shift racial and cultural boundaries irrespective of their apartheid privileged backgrounds and the current societal perception of white people. Furthermore, this study illustrates that for these students, being a white South African no longer means privilege and superiority but inclusiveness and multiracialism.

The main focus is on what makes them who they are in the democratic South Africa. We investigate the conversations their parents had with them about both apartheid and the democratic South Africa and how such conversations impacted their perceptions of themselves and others. Furthermore, we investigate the meanings derived from the experiences of living in the democratic South Africa, as a white young person, and probe into those experiences that give them hope for their future aspirations.

\section{Background}

South Africa is not different from the other parts of the world in experiencing the demographic shifts from colonisation, migration and immigration (Meier \& van Wyk 2012:19). In the last two decades, there has been social change brought about by political changes, the abandoning of the apartheid policies and the influence of globalisation, resulting in an identity and culture change. With the election of a democratic government in South Africa in 1994 and the legal promulgation of a new constitution, Afrikaner culture and 'whiteness' was no longer a privilege (Puttick 2011:1). The new constitution and regulations that were introduced no longer favoured white people; in fact, they disadvantaged them because they were meant to redress the inequalities of the past. Various laws and regulations such as Black Economic Empowerment (BEE) and Affirmative Action (AA) policies were introduced, so as to give more opportunities to previously disadvantaged (non-white) citizens. With the democratic government came freedom of choice, freedom of association and equal rights for all. There were no longer exclusive schools for white children and areas designated for only white people. With the integration of the school system in South Africa, the predominantly white government schools were now admitting more and more black learners. This meant that white children were becoming more exposed to black people and black children at an early age. Such a change was not just political; it obviously influenced how white people see themselves, white youth in particular, considering that that their parents were privileged by the apartheid regime. The end of white privilege and white supremacy meant that white South Africans would have to rethink their identities and how they fit into the broader South African community. Various questions around what should be the role of white people in the new South Africa have been posed (Alexander 2007; Franchi \& Swart 2003; Rasmussen 2001; Steyn 2001, 2004), as well as questions about what Steyn (2001:59-63) calls the 'grand white narrative ${ }^{1}$ and the best way to dispel it in the South African society. Njabulo Ndebele (2000:46-47) suggests a need for white South Africans to develop a 'new sense of cultural rootedness'. Ndebele's (2000) contention is that if white South Africans are to find a legitimate way of belonging in South Africa, they will have to engage critically with their identity and their apartheid privileged 'whiteness'. This suggests that they have to embark upon a process of looking at themselves differently as part of the democratic South Africa, and this is clearly not an easy process. For white people, obviously these questions are not just political abstracts, these are psychological, emotional and identity interrogations. Those who were there during apartheid have an experiential point of reference, while the youth who were born in democracy are in limbo, as they only have their parents and history as their point of reference. With such a limited point of reference, one wonders how white youth handle the fact that the white race was once privileged and presently it is not. As a point of reference, what stories do their parents narrate to them? To what extent do such stories negatively or positively affect them? It is against such a background that we endeavour to examine what must be the contemporary identity construction of young white people born in post-apartheid South Africa.

We took great interest in knowing how the so-called 'born free' young white people deal with sharing with black people the same space in schools, public transport and public facilities. This paper takes a particular interest in the studies of neighbourhoods of Afrikaans-speaking white people. Yes, to some extent white South Africans do share many common identifications and assumptions of privilege, but there are also significant differences in how their 'whiteness' is being reframed in post-apartheid South Africa (Steyn 2004:144). Theoretically, this study is located in the broader discussion on youth identities and youth cultures, with the intention to better understand how young white people see themselves in the globalised world where they are no longer just local citizens but citizens of the world.

\section{Youth identity as a socially constructed category}

While many seem to understand what is intrinsically meant by 'identity', it is perhaps fruitful at this point to clarify that identity is socially constructed, fluid and the product of human thinking, discourse and action (Puttick 2011:1). Any identity formation process entails continuous contestations and negotiations (Roderick, Postmes \& Spears 2008:168-169). An individual typically occupies more than one identity at any given moment and these identities can shift according to the subjective position of the individual (Puttick 2011:1). We constitute and invent ourselves through our interactions with others. There is no identity without the other and the old African proverb of $u b u n t u$ and coexistence explains this thought very well by pointing out that umuntu ngumuntu

1.This is a narrative where being white and European is seen to represent everything good and powerful - it is also a dominant system of beliefs against which everything is measured. 
ngabantu (a person is a person by other people). The literal translation of this phrase puts it interestingly: that, 'because I $\mathrm{am}$, therefore we are and because we are, therefore I am'. This places the identity of an individual in the collective identity of others. If we take into consideration the significance of an individual and the collective identity, identity is therefore about belonging, about what one has in common with others and also what differentiates one from others.

Also, identity is constructed and modified in relation to the individual's social, cultural and historical context. In the process of identity construction, through interactions with others, previously held beliefs, knowledge, understandings and values become destabilised. As such, new social meanings are created, generating new social roles, which inherently disrupt previously held identities through exposure to a relatively more diverse peer group, as well as through other agents (Willis 1990:12). Furthermore, it is acknowledged that all young people experience one aspect or another of the contemporary 'social condition' of youth (Willis 1990:12). One can argue that identity is not something one has but something that develops during one's whole life. Identity is not static or predetermined but rather varies in different contexts (Gutiérrez \& Rogoff 2003:20). Especially among the youth, it is socially constructed throughout one's life, as individuals interact with people and society at large. Thus, identity is important for social interactions in everyday life, because it affects trust formation and group participation.

Various studies exist on how youth socially construct their identities, focusing on various topics, such as general youth cultures and identities, various cultural paradigms in relation to culture change, societies in transition, economic and labour systems, and political and government systems. Although approached from various fields, such studies have shown that youth from all races and cultures, urban and rural and at different times, have been able to redefine and regroup themselves to make meaning of their daily changes and environment. One interesting study on youth in transition was conducted by Nayak (2003) who begins by dissecting various perceptions on his own identity. He says that his parents saw him as Indian, his colleagues saw him as British but he sees himself as both Indian and British. Nayak's point is that his identity does not depend on how others define him but on how he sees himself in relation to his prevailing sociopolitical conditions.

Nayak (2003) conducted an ethnographic study on how global change affected white youth in a small town of Tyneside in 'White Highlands' in post-war Britain at the end of the twentieth century. Nayak (2003) argues that although the youth are labelled as 'deviant', they are merely frustrated and are faced with a socially constructed panic that is more about the identity of traditional Englishness in a divided closed society. Nayak (2003) suggests that the youth should be understood by looking at the fact that trends of globalisation are changing and moving forward at a very fast pace, thereby influencing cultural ways of life. Nayak's (2003) cultural identities seem to be no different from the South African youth caught between two worlds - which are the 'traditional' and the 'contemporary'. The traditional is characterised by trying to satisfy parents' expectancy of living and the contemporary is more about the reality of constructing meaning out of the new order in which they find themselves. The political changes in South Africa, the global influences and the contemporary changes call white youth to rethink their identity and sense of self.

\section{White youth identities during apartheid}

As much as this study takes more interest in cultural distinctiveness, one cannot overlook the fact that the Afrikaans-speaking population was more privileged because of their racial category (Jansen 2009:57). The study of 'whiteness' has emerged as an influential tool for analysing and interpreting the workings of power and privilege in numerous societies (Hage 1998; Lipsitz 1998; O'Meara 1997; Phoenix 1997). Various studies on 'whiteness' have shown that 'whiteness' is often a somewhat dominant and normative space against which difference is measured and only exists in so far as other racialised identities exist, such as 'blackness' (Steyn 2001). In this manner, 'whiteness' is frequently seen as a centre from which the self and others are perceived and understood. For this reason, white South Africans have always constructed their identities around 'whiteness'. The construction has always depended on supremacy and enlightenment, where the white culture was more superior and powerful than all other cultures. During apartheid, white privilege status and supremacy were never questioned. 'Whiteness' was seen as a continual social hierarchy which grants differential access to economic and cultural capital. On the contrary, darkness was often seen as the antithesis to 'whiteness'; the black people were considered by many to be inferior and subordinate (Fearon 1999; Mir \& Watson 2000; Rasmussen 2001; Steven, Duncan \& Bowman 2006).

Various studies on Afrikaans youth show that their conceptualisation of their identities has been influenced by Afrikaner ethnicism and the pursuit of a 'true' Afrikanerness; as a result, there was no way they could not see themselves as superior and pure (O'Meara 1997; Sibanda 2012; Steyn 2001; Vincent 2008). In order to maintain the continuation of Afrikaner pureness, the Afrikaans youth were influenced by various apparatuses of white Afrikaans culture, such as church or religion, sport (rugby), schooling system, peers and military organisation. For example, there have been studies that show how Afrikaans youth wrestle with dilemmas, such as the Afrikaner Broederbond and military training (O'Meara 1997). It is reported that during apartheid, white youths received intense military training which also served as a powerful socialisation tool (Conway 2008; Frankel 1984; Jansen 2009). Jansen (2009:85) asserts that if other circles of influence worked softly ... this aggressive military approach to their socialisation sealed any chances of dissent'. 
Regarding the influence of school on white youths' identities, Lambley (1980:198) observed that young white people have been brought up on values and perspectives of life that have always been expressed uniformly at every level of their society. He claims that the values and perspectives of life imparted to the young people at school from teachers and school books, at home from parents, church, from the media, television, radio, newspapers, magazines and the cinema established and reinforced identity. Jansen (2009:71-80) agrees with Lambley (1980) that during apartheid, there was a strong cultural cohesiveness that bound the white youth together. Jansen (2009:73) claims that almost every white boy played rugby at some stage of his childhood and that rugby is 'a powerful social circle in which identity is tied to achievement on the rugby field'. White churches were the prime and powerful instrument for transmitting apartheid politics and policies (Jansen 2009:73). The Dutch Reformed Church became the instrument to preach white superiority as a chosen and pure race (Jansen 2009:73). What the white youth experienced from an early stage was knowledge of a glorious past of struggle and achievement of white people against all odds (Mbembe 2008:12). The historical documentations of young people reflected demographic veracity and policies that were enforced by apartheid. The democratic South Africa has caught up with forces of globalisation, which are significantly influential in marking out a set of culture, identity and meaning, aligned to concepts such as 'multi-culturalism', 'universality' and 'cosmopolitanism'. Now, there has been a paradigm shift in the demographic landscape of South Africa. There is freedom of association and people can choose to live anywhere without infringing on anyone's rights. Thus, this change challenges one to look at the concept of culture as more than just a localised or 'tribalised' reference but rather as a diverse and 'holistic' engagement. Such a diverse engagement includes imperatives such as identity, ideas, representation, social construction, context, 'positionality', difference and institutional 'embeddedness'.

Walker (2005) has explored how change has unfolded across time in the lives of young white people of East London. The exploration was about how they have changed or stayed the same as the world has dramatically shifted around them, how they are formed by the past, but also against it. Walker (2005:51) found that the Afrikaner students' identities were formed at the nexus of competing discourses of transformations, or preserving the apartheid past, of language, culture and colour. There is also limited social mixing. Also, social and economic conditions shape and influence friendships. Walker further found out that young white people's lives are marked by race, racialised subjectivities and a past of racial separateness. After 1994, the centre tipped, heralding a renegotiation of their identities. A change in the flow of cultural information is one of the most defining aspects of the new South Africa (Steyn 2001:152). 'Blackness' and 'whiteness' are seen to have a pervasive impact on society. As such, individuals and groups may come to accept and internalise these constructs in their personal capacities and are thus often unable to change or contest them. Thus, social categories such as race, 'blackness' and 'whiteness' are often naturalised and viewed as being normative and often have the same necessity as laws which govern the natural world. 'Whiteness' is now no longer fixed but a site of change and struggle. The characteristics of 'whiteness' are heterogeneity, and feelings of guilt, fear and dislocation (Steyn 2001). Overall, 'whiteness' theories unanimously perceive that the meaning of 'whiteness' has indeed changed in recent times. For instance, in South Africa, white people are no longer privileged in the current democratic South Africa, although the economy is currently in their hands because of the privileges of apartheid; but, being a white South African does not necessarily translate into superiority.

\section{Fieldwork and methodology}

Part of this study was conducted by Thandiwe Bubulu in 2014, as part of her master's dissertation at the University of Fort Hare on white identities in post-apartheid South Africa. She interviewed white youth registered at various tertiary institutions in East London, between May and July 2014. Bubulu did not necessarily concentrate only on Afrikaansspeaking youth; she also interviewed white youth in general who also included English-speaking white students. She interviewed 10 young people, of whom 6 were Afrikaans speaking. In 2015, between August and October, a follow-up study was conducted and 20 white students who were of Afrikaner background, living in various areas of East London, were interviewed. In this instance, we concentrated more on Afrikaner youths' identities; as a result, our focus here is more on cultural identity than on racial division. However, one cannot look into Afrikaner identities and exclude race identity because of the fact that the apartheid context was identified by racial complexities. In 2014, Bubulu met participants once a week over 3 months. Also, as the supervisor of the Master's thesis, I went and visited them to see if proper procedures were followed. In July 2015, we requested the six leaners who were initially interviewed by Bubulu, to introduce us to other Afrikaans-speaking leaners, which they did, and as a result we ended up interviewing all of them between August and October 2015. During the 3 months we met them twice a week for the first month on a Monday and Thursday and thereafter we met them twice a month for 2 months. Therefore, this study is a result of the interviews and interactions that took place in 2014 and 2015.

The interview schedules used during the interviews were made up of semi-structured questionnaires which allowed participants an opportunity to express their opinion and perception without any pressure. The interviews were recorded by both tape recorder and note taking. During the interviews, participants were free and they only spoke about a number of issues related to them as Afrikaner youth living in the democratic South Africa.

Participants were not forced to participate (voluntariness) and were informed of their rights and that they could also withdraw from the study any time if they wished to do so. Pseudo names were used for referring to participants in order to protect their true identity. Each participant signed a consent form which explained that they participated in the 
study voluntarily and that no one coerced them to do so. Participants were not given anything in appreciation of their participation. It was observed in both instances in 2014 and 2015 that most participants were excited about the research and as a result they were always looking forward to it.

This study is not without limitations. One of the limitations is that the fieldworkers were black Africans which might have resulted in response bias, where the participants tell the fieldworkers what they think they want to hear. This might be the consequence of the fact that participants were aware of the general perception of black people about white people, and as a result during this study they could have tried their level best to show that they are not racist and this might have compromised the findings of the study. In recognition of the above limitation, researchers assured participants that the interviews were for research purposes and that pseudo names will be used while reporting findings and that their true identities will not be revealed. Also, the researchers explained the significance of research to participants and further emphasised the importance of being themselves and not pretending to be what they were not. During the information session, participants seemed to have understood the importance of this study, and this was clear from their interaction with the researchers. For example, all of them showed an understanding of the role and meaning of research in documenting participants' feelings, experiences and perceptions.

The second limitation is that the research sample consists of white students who normally socialise with black students on a daily basis, thereby resulting in them not being representative of the research population. The third limitation is that the research sample is small; therefore, it is not representative of the larger population. As a result, findings cannot be generalised to the larger population. In addition, this study does not provide a gender comparison of the perceptions and experiences of the participants. However, as previously stated, this research is a qualitative study, which aims at understanding the meaning behind the discourses, reflective of the target population, and not necessarily using the results for statistical purposes. In acknowledging these limitations, the study nonetheless does highlight the perceptions and lived experiences of young Afrikaner youth living in East London.

\section{Brief discussion on participants' background}

Including Bubulu's participants, the number of participants in total was 26, and their ages were between 20 and 25, with a gender distribution of 17 women and 9 men. Participants were born in various places in South Africa but were now permanent residents of either East London or King Williams Town. All participants study in East London for financial reasons. The participants stated that if they were given the opportunity, they would have studied at better universities outside East London. For instance, David said:
'Most better universities like University of Cape Town, Wits University and Rhodes are expensive for me and if I were to go there my parents would not afford paying residence for $\mathrm{me}^{\prime}$. (Male, 24)

While Elizabeth said; 'obviously I would have loved to study at Wits University in Johannesburg but my parents would not afford to pay rent for me'. It seems as much as participants were worried about exorbitant fees at other universities, they were also concerned about accommodation if they were to study outside East London; as a result, all participants were staying at their parents' homes and some with their relatives.

\section{Ethical consideration}

The ethical clearance for this study was granted by the University of Fort Hare and this study forms part of the National Research Foundation (NRF) Thuthuka Grant on youth cultures and identities, post apartheid.

\section{Discussion on the interview results Participants' conceptualisation of apartheid and the white privilege}

All participants were well aware of the reputation attached to their skin colour and the fact that they were of apartheid privileged Afrikaner background. Although a few of them saw nothing wrong with apartheid, most of them were shameful of such a privileged past. Those who saw nothing wrong with such a past expressed the view that apartheid was God's purpose and that now that it is over, there is no reason to talk about it. Those who saw nothing wrong with apartheid were also irritated by the question of apartheid privilege. For example, David said:

'I really don't like to talk about this subject, I only agreed because of my friends, I'm not racist but I don't see anything wrong with apartheid, it was God's purpose and it must remain in history'. (Male, 24)

Marlene (female, 24) was also irritated by the question regarding privilege and she responded: 'Even if we were privileged then, now we are not, so what's the relevance of asking me about my privileged apartheid situation?' David further said that he does not see anything wrong with apartheid and the fact that they were privileged because now they were no longer privileged; his parents were now struggling to pay his university fees while black students were studying for free. Those who were shameful of the apartheid past noted that they felt ashamed of what their grandparents and parents did to black people. Emily said that:

'Even though I was not there during apartheid but I feel sad for what our grandparents did to black people as much as my parents have raised me well and are now supporting me through my education but sometimes I am not proud of being white, I don't see myself as special or privileged but I am ashamed of my past'. (Female, 24) 
In turn, Rhoda said:

'There is really nothing to be proud of; it is such a shameful past, whenever I read and hear about how black people were treated by white people I become ashamed of being white'. (Female, 22)

Elizabeth said: 'Yes, I am fully aware of the apartheid privilege, but I am sorry for what our grandparents did to black people'. (Female, 24)

Most of them did not necessarily blame themselves but expressed regret in the apartheid system and its policies. Some even said that if there was a way for them to compensate black people, they would do that. Rhoda said:

'I live a simple life like most of the black kids in the university and some of them are even better off than me, but still if there was a way to compensate them for what apartheid did to them I would compensate them'. (Female, 22)

Emily said:

'Most of my classmates come from poorest families and they made me realise what poverty has done to them due to apartheid laws'. (Female, 24)

\section{Emily further noted that:}

'One can see that poverty among black people has not only been financially but even emotionally, I noticed how my black friends treated me when I first approached them for friendship. They looked down on themselves and respected me as umlungu'. (Female, 24)

She also noted that it took a long time for her black friends to see her as normal just like them. Rhoda on the contrary said that as much as they were privileged during apartheid, presently some white people were poorer than other white people and even poorer than some black people. For example, her family is poorer than some of the black people. Even though a very few participants, in fact only two out of the total number of participants, took pride in apartheid and its policies, not all the participants were proud of it, and some of them even expressed regret about the consequences of apartheid. There was a general acknowledgement of the apartheid system as a system that benefited all white people, but there was also a point made that not all white people are rich today, and that some were even poorer than some black people.

\section{At what age or what point did participants become aware of apartheid?}

This question sought to better understand where, how and who first talked to participants about race, apartheid or white superiority, the extent to which this was done and the perspective from which the story was told. One of the research aims was to identify the first instance of influence on the subject and the role such influence has on their current perception on the subject. As already mentioned, all participants were born between 1991 and 1998 and did not have a direct experience of apartheid; although some were born in 1991, they were only 3 years old in 1994 and therefore were too young to know the difference. Most participants heard about apartheid's history from a young age at home from their parents and other family members, while a few heard about it from school. Those who heard about it from school were taught by primary school teachers on the subject of history of white people and pride in their heritage. Elizabeth said:

'I studied at a primary school where there was only white people and I vividly remember hearing about apartheid from primary school, but it was not necessarily called apartheid, but it was a general history of how white people came and settled in South Africa and the role they played in developing this country'. (Female, 24)

Most of those whose parents told them about their history and heritage were told about how evil black people are and were also told about communism and some of the black people who were imprisoned because they were communists. Furthermore, it was emphasised to them that before 1994, white people lived a peaceful life away from black crime and corruption. David recalled how his parents used to tell him to work hard and get involved in family business, because 'now South Africa is in the hands of communists'. Johann recalls that when he was in Grade 8, when he had just enrolled at a multiracial high school, his father warned him about black people. He said:

'I arrived at home and told my father that I had a new friend and he was excited and asked me more about my friend and I told him that he was a black, my father gave me a long lecture and warned me to be careful of black kids because their parents are not good'. (Male, 24)

Frieda also received a lecture from her parents after they saw her with black children when they went to pick her up from school. Emily said that her parents were fine with her having black friends even from primary school, but in the beginning they would ask her what the black child used to talk about in order to establish whether they talked negative about white people or not. 'Actually I'm still friends with Vusi and as result of our strong friendship bond our parents also became friends' added Emily. A few said that their families would have specific meetings to talk about their history and not necessarily give them details of the situation of the time, and the emphasis was more on preserving their Afrikaner identity without giving them apartheid details. Rhoda said she vividly remembered her father saying to them 'my children it is important for us to teach you our history and heritage, because out there you will hear all sorts of bad stories about white people'. David said his father refused to take him to a multiracial school but took him to a school with white people only so that he could not hear bad stories about white people. Johann who studied at a multiracial school in Amalinda said that his mother did not necessarily have an unpleasant attitude towards black people, except that she told him that he needs to be careful about the fact that black people have a tendency of talking negative about white people and not all white people are bad. She further said, 'I had black friends from as early as primary school, because some were my class mates and my mother had no issue with that'. Most informants were never told or influenced about apartheid as 
a bad practice; in fact, it was only when they were in high school that they heard about the term and it was mostly used on TV during news, which they also hardly watched. Most said that while they were young even the TV channels they watched were those of white Afrikaans speakers and for some reasons they were never encouraged to watch other channels like SABC 1 and SABC 2. Some said they heard about Nelson Mandela, who was the first black president, from an early age, and it was their interest in this person that made them want to watch news more often, as the news often used the term 'apartheid' whenever it reported on Nelson Mandela and the African National Congress (ANC). Peter recalls that when they used to watch news on the TV, they would talk about Mandela who was the president and who suffered under apartheid and would ask his father what exactly did Mandela do to deserve such suffering? His father responded 'it's South African history when white people and black people were fighting'. He felt that his father avoided answering exactly what the issues were and this frustrated him and made him to want to know more about President Mandela and black people in general.

\section{How were participants influenced by their parents' perception of black people?}

The effect and the impact of what they were told by teachers, parents and other family members varied, with most saying it made them more inquisitive about black people. Some said after their parents' negative talk and influence about black people, they stayed away from black children for some time, but ended up befriending some other black children at a later stage. Some of them mentioned that they had already been exposed to black children prior to their parents' negative influence, and they did not see anything wrong with them. Beyond their parents' influence, they wanted to hear and find out for themselves if what they heard was true. Sonia said:

'I remember after my father told me how bad and immoral black people were, I developed interest to get to know them better and I did not see what my father spoke about'. (Female, 23)

Emily said:

'At the beginning I also did not like black people but the more I interacted with them in high school, I realised that they are not so bad and a result I am now dating one of them'. (Female, 24)

\section{What does it mean to be a young white person in post-apartheid South Africa?}

For most participants, being a white young person in the democratic South Africa is the most difficult thing. At the grass-root level, they felt accepted by their classmates and have developed good relationships with people of all races, but their main concern was the democratic laws that seem to bring down white people. Over and above these laws, they were also discouraged by the general perceptions of black people about them and the statements by politicians which suggest that white people will never genuinely care for black people. Their main concerns are that they feel disadvantaged, even though apartheid advantaged their parents, and consequently they experienced financial difficulties in the same manner as many black people. Marlene said, 'All the laws in this country favour black people and white people are left to suffer'. The An other said 'not all white people are privileged you know'. One said:

'Look at me I am studying here in East London so I could stay at home, my parents could never afford rent otherwise I could have decided to study at other better universities'. (Rian, male, 21)

For them to be young and white South Africans in the democratic South African means one must work much harder than black youth, more especially if one is a white South African and comes from a poor family. Emily said 'even when we finish studying still we won't get jobs, because they are meant for black people and it seems that now we have to pay for our parent's sins'.

Joseph noted that:

'One day I would want to raise my children over a clear conscience, a clean slate you know, not on what my parents have experienced, I therefore would love us young people of different races to move on with our lives and not be influenced by what our parents have experienced'. (Male, 23)

For most participants to be a white young person in the democratic South Africa means living a life of constant adaptation. In the context of affirmative laws that favour black youth, white youth have to get used to being overlooked and adapt to constant changes. They regret that apartheid divided the society and further feel that apartheid is over and society must to be ready to change along with it. Most of them appreciate the fact that everyone is free under the new South African democratic laws and policies, even though some of these laws oppress them. These include freedom of choice, freedom of association and freedom of speech.

\section{'We are all same', the most popular phrase used by participants}

'We are all the same' is the most popular phrase used by participants in defining themselves and their state of being, in relation to other young people. This sameness relates to the fact that most of their parents work as teachers, school principals, police, social workers, church ministers and others in the private sector. Furthermore, they live in affordable areas like Amalinda, Greenfields, Quigney and West Bank. Like other black young people, some of them travel to school with their parents who drop them off, some take lifts with friends, while some use public transport. For example, Stacy stays in Amalinda and travels by taxi to school, while Rhoda who stays in Quigney walks to school because her parents cannot afford taxi fare. In her own words, Rhoda said:

'I walked to school with some of my friends and it feels healthy and that does not bother us, yes there are those who take the taxi but we can't afford it and so we have accepted it'. (Female, 22)

When asked whether the friends she walks with were black people or white people, she responded: 'does it really matter? I walk with black friends, for some reason I have been with 
them so much that colour does not matter anymore in defining them'. As much as participants acknowledge that apartheid privileged white people and disadvantaged black people, their issue is currently that their parents have to work like everybody else, and it is unfair to look at them differently and assume that they are well off. Rhoda said: 'some of my black classmates are better off than me and sometimes Kuhle, one of my classmates, buys me lunch when I don't have money'. Johann said 'not all white people are rich, maybe our grandfathers were but our parents work very hard just like black people'. Rhoda further said, 'I don't see myself in anyway different from black youth and the only difference is the skin and it does not mean I am privileged or better'. Peter also said:

'When I arrived in high school I tried to make friends with black learners, but I could see that they were avoiding me and some thought that I was better than them and it took a long time to finally convince them that we are all the same'. (Male, 21)

The participants also did not regard themselves better or more morally upright than black people. Some see themselves as South Africans first before the question of white privilege and therefore they tried their level best to reach out to some of their black classmates and friends so as to convince them that they are all the same. Some of the black youth easily accepted them while some resisted. As it will be mentioned later, some of the participants were dating while some have dated black people at some point.

\section{What is it that makes participants happy and hopeful?}

Their joy and hope depended on various things such as being accepted by black peers and coloured peers, on the changing political landscape and on achieving their ambitions. The biggest thing that makes them happy is when coloured and black youth accept them and when they are treated normally in classes at school. Furthermore, what makes them happy and hopeful is that one day, they will be accepted for who they are, not based on being white South Africans or privileged apartheid children. Also, their hope is on the changing political landscape in South Africa. For them, the ANC is a racist party that divides the society and they have hope in the inclusive laws that will be introduced by the Democratic Alliance (DA). There was a specific trust and hope that they expressed in the DA. For example, Samuel said, 'We participate in university politics and the Democratic Alliance Students Association (DASA) is our hope, there we have all races and we treat each other equally'. DASA is growing very fast and as a result in 2014, at the University of Fort Hare, the Student Representative Council (SRC) was DASA, and the same was the case in the Nelson Mandela Metropolitan University as well. Frieda said:

'Look who would have thought that the Democratic Alliance would grow and have more black people, even a black leader in Mr Musi Maimane. Now in the DA we have all races and we don't look at each other the same way our parents did'. (Female, 24)
The participants were also hopeful that they will complete their studies and secure employment, even though it might be difficult, but they are hopeful that in the end things will work out well for them. Peter who was doing his final year in law said: 'my uncle is a practising lawyer and after I finish my studies I plan to go and do my article at his firm and that really keeps me hoping'. Fred said: 'I am now engaged to my boyfriend and once we are done studying, we will both relocate to Cape Town and work there and that is what keeps me going'.

\section{What are their aspirations and future wishes for the democratic South Africa?}

Almost all the participants stated that it would be positive and empowering if the ruling classes promoted association, cooperation and unity among or within the different races. Without a unified rainbow nation, much conflict might be reborn, whereas the present young generation should be trying to move away from that. Some of them expressed the following:

- Young people in the democratic era wish for peace and harmony among the different races; even though there are different associations, the youth should rather learn from each other's differences and build a broader nation with better and bigger opportunities for all, regardless of the different races and identities.

- Learning from each other's differences and creating the best out of them could open many brighter doors and opportunities for all South African citizens and would also encourage other nations as well.

\section{Discussion and conclusion}

This study suggests that to a large extent, white youth have been negatively influenced against black people. This influence has been enforced in the pretext of 'Afrikaner pride' and the intention was to make them think of themselves as superior to others. Furthermore, efforts were made by their parents and family members to isolate them from black influence and to some extent some parents moved them from certain schools that admitted black learners, while some denied them an opportunity to listen to SABC news that could expose them to negative identities of white people. However, this study shows that despite all influences they received from parents and despite isolation, these young people are still able to make up their own minds about who to associate with and even going to the extent of engaging in racially mixed relationships that were not approved by their parents. One such example is that of one of them decided to date a black student, with their relationship resulting in their families reaching out to each other.

This study shows that in spite of parents' influence on apartheid and black hatred, young people are able to make up their minds on who they want to be and who they want to associate with. Their identity is no longer defined by apartheid's influence, and they are able to shift boundaries and spaces of race and culture. This is contrary to the small 
white superior world driven by influences on military training, rugby, Dutch Reformed Church and secluded schools system. Their identity and sense of belonging is influenced by their interaction with other black youth and coloured youth. This study shows that white youth are now defining their own identity, which includes interaction with youths of other races as equals - just like Nayak (2003) a person of Indian origin who grew up in England and was seen by his parents as Indian, by his colleagues as British, but who carved his own identity which included being both Indian and English. The findings of this study agree with Nayak's (2003) argument that to some extent one's identity among the youth does not necessarily depend on how others define one, but on how one perceives oneself in relation to one's socio-political contexts.

There is also a sense that the laws that are introduced in South Africa are meant to punish all white people; as much as they recognise the injustices and the results of apartheid, they also feel that they are being made to pay for their grandparents' and parents' sins. This also brings to light the questions of white privilege and the black disadvantaged; their issue is that as much as white people could have been privileged in apartheid, after 20 years of democracy some black youth are now better off than white youth. A white female student made the following comment on Facebook during the \#FeesMustFall Campaign (October 2016):

'The political parties are gaining by driving a wedge between all races, I supported the FMF, but know ... I don't know, once again I find myself questioning my place in this country - the only country that I know and love. I am privileged, but not in any financial sense - why would I be studying NOW if I have could afforded it when I was 18?? I am privileged because I know how the world works, I have been exposed to different things from a young age and was brought up in a safe and sometimes over protective environment. Do I agree with the fact that 'we let you live' ... I am so shocked and appalled that I don't even know what to say. Free education for the poorest of the poor, the rest must pay on a sliding scale. I have watched the Wits protestors get into their big black Mercedes-Benz or Audi or BMW and they have the audacity to tell me that I don't know about financial struggle or any struggle for that matter'. (Facebook post, 5 October 2016)

Her dilemma is that she is a white South African and yet poorer than some students who participated in the campaign. She raises an interesting question on the meaning of the term 'poor'. She questions the idea that being a white South African she cannot be poor. Furthermore, she questions the state of a black South African and yet privileged students who drive expensive cars that some white students cannot afford. In this way, just like in the findings of this study, not all white students are rich. Therefore, the \#FeesMustFall Campaign should not be about black students and white students but about students who cannot afford tertiary tuition, irrespective of their skin colour.

This study also shows that there is a strong feeling of anger and bitterness towards democracy and an observation that it has come to rob and steal what their parents have invested for them. There is a sense of victimisation and reverse revenge. They grew up in an era where all South African citizens were supposed to experience equality and nonracialism; however, it is not so, and as a result, they feel that it is the current government that perpetuates racism among youth. It seems as if the feelings expressed by participants is what many white South African youth are trying so badly to express just across the racial fence. It seems that a lot of young white South Africans are saying that they are not responsible for apartheid, they are not racist, they are for racial harmony and coexistence with their black neighbour, but no one seems to hear them out because of their skin colour. The last interesting part is their interests and their hope in politics. They eloquently express their disappointment in the ANC as a party that divides people according to racial lines and also their hope in the DA as a party of the future and a symbol of non-racialism. For them, it seems that the DA is not just a political party but a safe and non-racial space where they meet as youth of all races. One cannot speculate on the exact reasons why this group of youth have been able to go beyond racial boundaries and racial identities, but at least we have a clue that most of them come from middle-class white families that live a simple life which is the same as most black students in East London.

In essence, what participants have in common with some black students in their classes and in their circles is their socioeconomic conditions. They live in the same areas, which are affordable for a number of black people in East London, and also their parents who are not necessarily successful business people; most of them are employed as nurses, teachers or police. It is their socioeconomic conditions that contribute to how they perceive themselves as equal and the same as black youth; as a result, their identity is drawn from a more integrated society.

\section{Acknowledgements Competing interests}

The authors declare that they have no financial or personal relationships which may have inappropriately influenced them in writing this article.

\section{Authors' contributions}

T.B. initiated the proposal for this article. L.N. was the study leader and supervised the research process. T.B. conducted most of the interviews while L.N. provided the conceptual framework for this article.

\section{References}

Alexander, L., 2007, 'Invading pure space: Disrupting black and white racially homogenised spaces', South African Journal of Psychology 37(4), 738-754. https://doi.org/10.1177/008124630703700405

Beall, J., Gelb, S. \& Hassim, S., 2005, 'Fragile stability: State and society in democratic South Africa', Journal of Sothern Africa Studies 31(4), 681-700. https://doi.org/ 10.1080/03057070500370415

Conway, D., 2008, "Somewhere on the border- of credibility": The cultural construction and contestation of "the border" in white South African Society', in
G. Baines \& P. Vale (eds.), Beyond the border war: New perspectives on Southern Africa's late-cold war conflicts, pp. 75-93, UNISA Press, Pretoria. 
Dyer, R., 1997, The matter of whiteness, Routledge, London.

Fearon, J., 1999, What is identity (as we now use the word)?, unpublished paper.

Franchi, V. \& Swart, T., 2003, 'From apartheid to affirmative action: The use of 'racial markers in past, present and future articulations of identity among South African Students', International Journal of Intercultural Relations 27(2), 209-236. https:// doi.org/10.1016/S0147-1767(02)00093-7

Frankel, P., 1984, Pretoria's preatorians: Civil military relations in S.A., Cambridge University Press, Cambridge.

Gibson, J. \& MacDonald, H., 2001, Truth_Yes, reconciliation_Maybe: South Africans judge the truth and reconciliation process, research report, Institute for Justice judge the truth and reconciliation process, research report, Institute for
and Reconciliation, Institute for Justice and Reconciliation, Rondebosch.

Goga, S., 2010, 'Rhodes students love to get drunk': Race, ritual and the legitimation of the authentic Rhodes student', South African Review of Sociology 41(2), 41-50. https://doi.org/10.1080/21528586.2010.490382

Gutiérrez, K.D. \& Rogoff, B., 2003, 'Cultural ways of learning: Individual traits or repertoires of practice', Educational Researcher 32(5), 19-25. https://doi.org/ 10.3102/0013189X032005019

Hage, G., 1998, White Nation: Fantasies of white supremacy in multicultural society Pluto Press, Sydney.

Jansen, J.D., 2009, Knowledge in the blood: Confronting race and the apartheid past, Stanford University Press, Cape Town.

Lambley, P., 1980, The psychology of apartheid, University of Georgia Press, Athens.

Lipsitz, G., 1998, The possessive investment in whiteness: How white people profit from identity politics, Temple University Press, Philadelphia, PA.

Mbembe, A., 2008, 'Passages to freedom: The politics of racial reconciliation in South Africa', Public Culture 20(1), 5-18. https://doi.org/10.1215/089923632007-012

Meier, E.M. \& Van Wyk, C., 2012, Multicultural education: A manual for the South African teacher, 2 nd edn., Van Schaik, Pretoria.

Mir, R. \& Watson, A., 2000, 'Strategic management and the philosophy of science: The case for a constructivist methodology', Strategic Management Journal 21 941-953. https://doi.org/10.1002/1097-0266(200009)21:9\%3C941::AID-SMJ141 \%3E3.0.CO;2-D

Nayak, A., 2003, Race place and globalisation, Berg, New York.

Ndebele, N., 2000, 'Iph'indlela? Finding your way into the future', Social Dynamics 26(1), 43-55. https://doi.org/10.1080/02533950008458685
O'Meara, D., 1997, 'The Afrikaner Broedebond 1927-1948: Class vanguard of Afrikaner Nationalism', Journal of Southern African Studies 3(2), 156-186. https:// doi.org/10.1080/03057077708707970

Phoenix, A., 1997, “I'm white! So what?": The construction of whiteness for young Londoners', in M. Fine, L. Weis, L. Powell \& L. Mum Wong (eds.), Off white: Readings on race, power, and society, Routledge, New York.

Puttick, K., 2011, 'First year student's narratives of race and racism in post-apartheid South Africa', master's thesis, University of Witwatersrand, Johannesburg.

Rasmussen, B., 2001, The making and the unmaking of whiteness, Duke University Press, Durham.

Roderick, I.S., Postmes, T. \& Spears, R., 2008, 'Identity formation in multiparty negotiations', British Journal of Social Psychological 47, 167-187. https://doi. org/10.1348/014466607X216124

Sehlongonyane, M.F., 2015, 'Empty signifiers of transformation in participatory planning and marginalisation of black people in South Africa', Planning Practice \& Research 30(1), 83-100. https://doi.org/10.1080/02697459.2015.1008803

Sibanda, O., 2012, 'Social pain and social death: Poor white stigma in post-apartheid South Africa, a case of West Bank in East London', Anthropology Southern African 35(3-4), 81-90. https://doi.org/10.1080/23323256.2012.11500027

Soudien, C., 2010, 'Certainty and ambiguity in youth identities in SA: Discourses in transition', Discourse: Studies in the Cultural Politics of Education 22(3), 311-326. https://doi.org/10.1080/01596300120094352

Steven, G., Duncan, N. \& Bowman, B., 2006, 'Ethnicity: It's about making a difference', in G. Stevens, V. Franchi \& T. Swart (eds.), A race against time: Psychology \& challenges to deracialisation in South Africa, pp. 1-72, ABC Press, Epping.

Steyn, M., 2001, 'Whiteness just isn't what it used to be' White identity in South Africa, SUNY Press, New York.

Steyn, M., 2004, 'Rehabilitating a whiteness disgraced: Afrikaner white talk in postapartheid SA', Communication Quarterly 52(2), 143-169. https://doi.org/10.1080/ 01463370409370187

Vincent, L., 2008, 'The limitations of "inter-racial contact": Stories from young South African', Ethnic and Racial Studies 31(8), 1426-1451. https://doi.org/10.1080/ 01419870701711839

Walker, M. 2005, 'Race is nowhere and race is everywhere: Narratives from black and white South African University students in post- apartheid South Africa', British Journal of Sociology of Education 2, 41-54. https://doi.org/10.1080/0142569042000292707

Willis, P., 1990, Symbolic creativity, Open University Press, Britain. 